\section{Hubungan Kontrol Glukosa Darah Dengan Penurunan Vaskularisasi Perifer Pada Pasien Diabetes Mellitus}

Jurnal Keperawatan dan Pemikiran IImiah Janitra, F.E (2018). Hubungan Kontrol Glukosa Darah Dengan Penurunan Vaskularisasi Perifer Pada Pasien

Diabetes Mellitus.

Nurscope.Jurnal Keperawatan Pemikiran IImiah.

4 (3). 18-22

\author{
Fitria Endah Janitra ${ }^{1}$, Dinda Sandika ${ }^{2}$ \\ ${ }^{1}$ Dosen Fakultas IImu Keperawatan Universitas Islam Sultan Agung Semarang \\ ${ }^{2}$ Mahasiswa Fakultas IImu Keperawatan Universitas Islam Sultan Agung Semarang
}

\begin{abstract}
Abstrak
Pendahuluan: Diabetes Melitus (DM) adalah gangguan metabolik yang ditandai dengan peningkatan kadar glukosa darah. Komplikasi kronis DM mempengaruhi sirkulasi koroner, vaskularisasi perifer, dan pembuluh darah otak. Penurunan vaskularisasi perifer meningkatkan resiko terjadinya iskemia jaringan dan melemahkan status fungsional, untuk itu perlu dilakukan pengontrolan kadar glukosa darah. Islam mengajarkan kepada penganutnya untuk mengendalikan atau mengontrol pola makan, dimana pengaturan pola makan merupakan satu dari empat pilar pengelolaan diabetes. Metodologi : deskriptif analitik dengan desain penelitian cross sectional pada 67 responden dengan tehnik pengambilan sampel consecutive sampling. Hasil : terdapat hubungan yang bermakna dengan kontrol glukosa darah dengan penurunan vaskularisasi perifer pada pasien DM ( $p$-value 0.010). Diskusi : perlu dilakukan penelitian tentang intervensi keperawatan untuk mengontrol kadar glukosa darah.
\end{abstract}

Kata kunci : diabetes melitus, glukosa darah, vaskularisasi perifer.

\title{
Correlation Between Blood Glucose Control And Decrease Of Peripheral Vascularization In Diabetes Mellitus Patient
}

\begin{abstract}
Introduction: Diabetes mellitus (DM) is a metabolic disorder characterized by elevated blood glucose levels. Chronic complications of DM affect coronary circulation, peripheral vascularization, and blood vessels of the brain. Decrease in peripheral vascularization increases the risk of tissue ischemia and weakens functional status, therefore it is necessary to control blood glucose levels. Islam teaches to its believers to control their diet, where diet is one of the four pillars of diabetes management. Methodology: this is analytic descriptive research with cross sectional methods in 67 respondents taken by consecutive sampling technique. Results: There was a significant correlation within blood glucose control and decreased peripheral vascularization in DM patients ( $p$ value 0.010). Discussion: need further research regarding nursing intervention to control blood glucose.
\end{abstract}

Keywords : Diabetes mellitus, blood glucose, peripheral vacular

Corresponding Author:

Fitria Endah Janitra ${ }^{1}$, Universitas Islam Sultan Agung Semarang, Jalan Raya Kaligawe Km.4 Semarang

Utara. fitria.janitra@unissula.ac.id ${ }^{1}$ 


\section{PENDAHULUAN}

Diabetes Melitus (DM) adalah gangguan metabolik yang ditandai dengan peningkatan kadar glukosa darah akibat gangguan pada kerja insulin, sekresi insulin, atau keduanya (Black\&Hawks, 2009). Prevelensi Diabetes Melitus semakin meningkat setiap tahunnya, secara global tahun 2016 berjumlah 422 juta dan diperkirakan meningkat menjadi sekitar 592 juta penderita di tahun 2035 (WHO,2016). Jumlah penderita DM di Indonesia mencapai 9,1 juta dan menjadi peringkat ke 5 teratas diantara negara-negara dengan jumlah penderita diabetes terbanyak dunia (PERKENI, 2015).

Seseorang dikatakan menderita Diabetes jika memiliki gejala khas DM berupa poliuria, polidipsia, polifagia beserta pemeriksaan kadar glukosa darah sewaktu lebih dari $200 \mathrm{mg} / \mathrm{dL}$ dan kadar glukosa puasa lebih dari $126 \mathrm{mg} / \mathrm{dL}$ (Gustaviani, 2007). Diabetes melitus tidak dapat disembuhkan namun dapat dikelola sehingga kadar gula darah dapat terkontrol. Islam mengajarkan kepada penganutnya untuk mengendalikan atau mengontrol pola makan, dimana pengaturan pola makan merupakan satu dari empat pilar pengelolaan diabetes.

Salah satu faktor yang mempengaruhi terjadinya komplikasi kronis pada DM merupakan kontrol gula darah karena apabila tidak terkontrol glukosa darahnya akan timbul berbagai komplikasi baik akut maupun kronis yang salah satunya adalah penurunan vaskularisasi perifer (Fain, 2014). Penelitian ini bertujuan untuk mengetahui hubungan antara kontrol glukosa darah dengan penurunan vaskularisasi perifer pada pasien DM.

\section{METODE}

Penelitian ini menggunakan metode deskriptif analitik dengan desain penelitian cross sectional dengan teknik pengambilan sampel consecutive sampling yang melibatkan 67 pasien DM tipe 2 sebagai responden. Pengambilan data dilakuan pada bulan Desember 2017- Januari 2018 di ruang poli penyakit dalam RSI Sultan Agung Semarang. Pengambilan data diperoleh dengan anamnesa dan pengukuran tekanan darah pada tangan dan kaki responden. Data yang di dapatkan di olah menggunakan program statistik.

\section{HASIL}

Distribusi frekuensi responden berdasarkan umur, jenis kelamin, pekerjaan, dan lama menderita DM pada pasien DM di Rumah Sakit Islam Sultan Agung Semarang pada bulan Desember 2017 Januari $2018(n=67)$

\begin{tabular}{lcc}
\hline \multicolumn{1}{c}{ Variabel } & Frekuensi & Presentase (\%) \\
\hline Umur & & \\
$36-45$ tahun (dewasa akhir) & 6 & 9.0 \\
$46-55$ tahun (lansia awal) & 27 & 30.3 \\
$56-65$ tahun (lansia akhir) & 28 & 41.8 \\
$>65$ tahun (manula) & 6 & 9.0 \\
\hline Jenis Kelamin & & \\
Laki-laki & 20 & 29.9 \\
Perempuan & 47 & 70.1 \\
\hline Pekerjaan & & \\
Bekerja & 20 & 29.9 \\
Tidak bekerja & 47 & 70.1 \\
\hline Lama Menderita DM & & \\
$\leq 5$ tahun & 50 & 74.6 \\
$>5$ tahun & 17 & 25.4 \\
\hline
\end{tabular}


Tabel diatas menunjukkan hasil bahwa umur responden terbanyak terdapat pada umur lansia dengan distribusi frekuensi umur 56-65 (lansia akhir) tahun dengan jumlah 28 responden (41.8\%), jenis kelamin responden perempuan dengan jumlah 47 responden $(70.1 \%)$, dan tidak bekerja dengan jumlah 47 responden $(70.1 \%)$ dan telah menderita DM kurang dari 5 tahun dengan jumlah 50 responden (74.6\%).

Distribusi frekuensi responden berdasarkan kontrol glukosa darah dan penurunan vaskularisasi perifer pada pasien DM di Rumah Sakit Islam Sultan Agung Semarang pada bulan Desember 2017 Januari $2018(n=67)$

\begin{tabular}{lcc}
\hline \multicolumn{1}{c}{ Variabel } & Frekuensi & Persentase \\
\hline Kontrol glukosa darah & & \\
Terkontrol ( $\$ 00 \mathrm{mg} / \mathrm{dl})$ & 41 & 61.2 \\
Tidak terkontrol $(>200 \mathrm{mg} / \mathrm{dl})$ & 26 & 38.8 \\
\hline Penurunan Vaskularisasi Perifer & & \\
Tidak Terjadi & 9 & 13.4 \\
Terjadi & 58 & 86.6 \\
\hline
\end{tabular}

Tabel diatas menunjukkan kadar glukosa darah sewaktu dan penurunan vaskularisasi perifer, frekuensi terbanyak adalah gula darah terkontrol dengan jumlah 41 responden $(61.2 \%)$ dan terjadi vaskularisasi perifer 58 responden (86.6\%).

Hubungan Kontrol Glukosa Darah dengan Penurunan Vaskularisasi Perifer di Rumah Sakit Islam Sultan Agung Semarang pada bulan Desember 2017 - Januari 2018 (n=67)

\begin{tabular}{|c|c|c|c|c|c|}
\hline & \multicolumn{4}{|c|}{ Penurunan Vaskularisasi Perifer } & \multirow{3}{*}{ Nilai $p$} \\
\hline & \multicolumn{2}{|c|}{ Tidak Terjadi } & \multicolumn{2}{|c|}{ Terjadi } & \\
\hline & $\mathbf{n}$ & $\%$ & $\mathbf{n}$ & $\%$ & \\
\hline Terkontrol & 9 & $13.4 \%$ & 32 & $47,7 \%$ & 0.010 \\
\hline $\begin{array}{l}\text { Tidak } \\
\text { Terkontrol }\end{array}$ & 0 & $0 \%$ & 26 & $38.8 \%$ & \\
\hline total & 9 & $13.4 \%$ & 58 & 86.6 & \\
\hline
\end{tabular}

Tabel diatas merupakan hasil uji Chi-Square yang didapatkan nilai $p 0.010(<0.05)$ maka dapat diartikan bahwa ada hubungan yang signifikan antara kontrol glukosa darah dengan peurunan vakularisasi perifer di Rumah Sakit Islam Sultan Agung Semarang dengan jumlah 67 responden.

\section{PEMBAHASAN}

Dalam penelitian ini didapatkan bahwa sebagian besar responden termasuk golongan lansia (81.1\%), hal ini sejalan dengan penelitian Purnamasari (2014) yang menyebutkan bahwa bertambahnya umur merupakan faktor resiko DM. Seseorang yang berumur 45 tahun ke atas beresiko 8 kali lebih besar mengalami penyakit diabetes mellitus dibandingkan dengan seseorang yang berumur kurang dari 45 tahun (Kekenusa, Ratag, \& Wuwungan, 2013). 
Jenis kelamin terbanyak dalam penelitian ini adalah perempuan (70.1\%). Hal ini sejalan dengan data dari IDF (2013) dan Balitbangkes (2013) yang menyebutkan bahwa jumlah perempuan penderita DM lebih banyak daripada laki-laki. Kejadian DM pada perempuan disebabkan karena perempuan lebih rentan mengalami obesitas karena pengaruh horon estrogen. Selain itu jumlah lemak tubuh perempuan lebih banyak dari laki-laki (Guyton\&Hall, 2007).

Status pekerjaan responden yang terbanyak adalah tidak bekerja $(70.1 \%)$. Hasil penelitian yang relevan lainnya menunjukkan bahwa pada umur yang lebih tua dampak penurunan kualitas hidup akan lebih dirasakan dibandingkan dengan umur yang lebih muda (Riviere, Irazola, Beratarrechea, Alcaraz, \& Carrara, 2015). Dalam penelitiannya dijelaskan bahwa pasien diabetes melitus mengalami penurunan kualitas hidup dalam hal yang berhubungan dengan salah satunya pekerjaan.

Dalam penelitian ini lama menderita DM responden terbanyak adalah kurang dari 5 tahun (74.6\%). Hasil penelitian yang relevan menjelaskan bahwa lama menderita penyakit DM berlangsung selama lebih dari 10 tahun, sebagian pria dan wanita dapat mengalami kerusakan di tangan dan kaki atau pembuluh darah di perifer, yang biasa dikenal Peripheral Vascular Disease (PVD). Kejadian ini berlangsung lebih cepat dan dapat terjadi lebih awal pada penderita diabetes dibandingkan dengan orang yang tidak menderita diabetes. Denyut pembuluh darah di kaki tidak terasa sama sekali atau lemah (Ndraha, 2014)

Hasil analisis statistik bivariat dapat disimpulkan bahwa ada hubungan yang signifikan antara kontrol glukosa darah dengan penurunan vaskularisasi perifer pada pasien DM dengan nilai p 0.010. Dengan bertambahnya usia dapat menyebabkan terjadinya pengerasan dan penurun fungsi pada sel endotel pembuluh darah sehingga mudah untuk terjadi angiogenesis, yang mana angiogenesis ini merupakan faktor kunci yang menyebakan terjadinya penyakit vaskuler pada pasien diabetes melitus (Markiewicz, Richard, Marks, \& Bradley, 2013). Penyakit vaskuler yang terjadi dapat diidentifikasi salah satunya dengan membandingkan tekanan darah sistolik tangan dan kaki. Apabila tekanan sistolik kaki lebih tinggi daripada tangan maka hal ini merupakan penanda terjadinya penurunan vaskularisasi perifer. Beberapa faktor lain yang mempengaruhi terjadinya komplikasi kronis pada penderita DM selain lama menderita DM dan umur diantaranya adalah jenis kelamin, kontrol gula darah, resistensi terhadap insulin dan neuropati perifer (Fain, 2014; Thiruvoipati, Kielhorn, \& Armstrong, 2015). Hasil penelitian relevan yang telah dilakukan menunjukkan bahwa risiko komplikasi mikrovaskuler dapat dikurangi dengan kontrol glikemik intensif. Pada diabetes melitus tipe 2 terjadi penurunan resiko komplikasi kardiovakuler sebesar $16 \%$ pada pasien dengan kontrol glikemik rutin (Skyler, Bergenstal, Bonow, Buse, Deedwania, \& Gale, 2009).

\section{SIMPULAN DAN SARAN}

Simpulan

Dalam penelitian ini telah di simpulkan bahwa dari karakteristik responden umur memiliki umur terbanyak pada umur lansia dengan distribusi frekuensi umur 56-65 (lansia akhir) tahun dengan jumlah 28 responden (41.8\%), kemudian jenis kelamin responden terbanyak terdapat pada jenis kelamin perempuan dengan jumlah 47 responden $(70.1 \%)$, pekerjaan responden terbanyak adalah tidak bekerja dengan jumlah 47 responden $(70.1 \%)$, dan lama menderita DM responden terbanyak adalah kurang dari 5 tahun dengan jumlah 50 responden (74.6\%). Sedangkan Dalam penelitian ini responden yang terjadi penurunan vaskularisasi perifer sebanyak 58 responden dengan persentase $86.6 \%$, kemudian yang tidak mengalami penurunan vaskularisasi perifer sebanyak 9 responden 
dengan persentase $13.4 \%$. Dan terdapat hubungan yang signifikan antara kontrol glukosa darah dengan pnurunan vaskularisasi perifer pada pasien DM di RS. Islam Sultan Agung Semarang.

Saran

Saran dalam penelitian ini dapat disimpulkan bahwa bagi Profesi Keperawatan, bagi institusi, bagi masyarakat, perlu dilakukan pemantauan terhadap seluruh pasien DM untuk mengetahui komplikasi yang mungkin terjadi. Bagi masyarakat dengan penyakit diabetes melitus (DM) diharapkan dapat melakukan pencegahan komplikasi dengan memperbaiki pengobatan, kontrol gula darah secara rutin serta memperbaiki gaya hidup dengan cara olahraga dan mengatur pola makan. Penelitian selanjutnya perlu dilakukan terkait intervensi mandirikeperawatan untuk mengontrol kadar glukosa darah.

\section{KEPUSTAKAAN}

Dinkes Kota Semarang. (2011). Profil Kesehatan Kota Semarang. Semarang: Dinkes Kota Semarang.

Ermawati. (2013). Penatalaksanaan Keperawatan Diabetes Melitus Terpadu. Jakarta: Mitra Wacana Medika.

Fain, J. A. (2014). Keperawatan Medikal Bedah Managemen Klinis untuk Hasil yang Diharapkan. Jakarta: Salemba Medika.

Gustaviani, R. (2007). Diagnosis dan Klasifikasi Diabetes Melitus dalam Buku Ajar Ilmu Penyakit Dalam, Edisi ke-4. Jakarta: FKUI : Hal 1857-1858.

Jelantik, I. M., \& Haryati, E. (2014). Hubungan Faktor Risiko Umur, Jenis Kelamin, Kegemukan dan Hipertensi dengan Kejadian Diabetes Mellitus Tipe II di Wilayah Kerja Puskesmas Mataram. Jurnal Media Bina Ilmiah 39, vol 8 (no 1).

Markiewicz, M., Richard, E., Marks, N., \& Bradley, A. L. (2013). Impact of Endothelial Microparticles on Coagulation, Inflammation, and Angiogenesis in Age-Related Vascular Diseases. Journal of Aging Research, Vol. 2013 ID 734509; 1-11.

Ndraha, S. (2014). Diabetes Melitus Tipe 2 dan Tatalaksana terkini . Leading Article, Vol. 27, No. 2.

Purnamasari, D. (2014). Buku Ajar Ilmu Penyakit Dalam Edisi Keenam Vol 2. Jakarta: Salemba Medika.

Riviere, A. P., Irazola, V., Beratarrechea, A., Alcaraz, A., \& Carrara, C. (2015). Quality of Life in Type 2 Diabetes Mellitus Patients Requiring Insulin Treatment in Buenos Aires, Argentina: a CrossSectional Study. International Journal of Health Policy and Management, 4(7), 475-480.

Skyler, J. S., Bergenstal, R., Bonow, R. O., Buse, J., Deedwania, P., \& Gale, E. A. (2009). Intensive Glycemic Control and the Prevention of Cardiovascular Events: Implications of the ACCORD, ADVANCE, and VA Diabetes Trials. Journal of the American College of Cardiology, Vol. 53, No. $3: 298-304$.

Thiruvoipati, T., Kielhorn, C. E., \& Armstrong, E. J. (2015). Peripheral Artery Disease in Patients With Diabetes: Epidemiology, Mechanism, and Outcomes. World Journal of Diabetes, Vol 6(No 7): 961-969. 